\title{
Construction and in vivo/in vitro Evaluation of a Nanoporous lon- Responsive Targeted Drug Delivery System for Recombinant Human Interferon $\alpha$-2b Delivery [Corrigendum]
}

Liu $\mathrm{H}$, Zhu J, Bao $\mathrm{P}$, et al. Int $J$ Nanomedicine. 2019;14:5339-5353. image for the control and $5 \mu \mathrm{g} / \mathrm{mL}$ samples. The correct Figure 5 is as follows.

The authors have advised Figure $5 \mathrm{G}$ on page 5347 is incorrect. The authors inadvertently included a duplicate

A
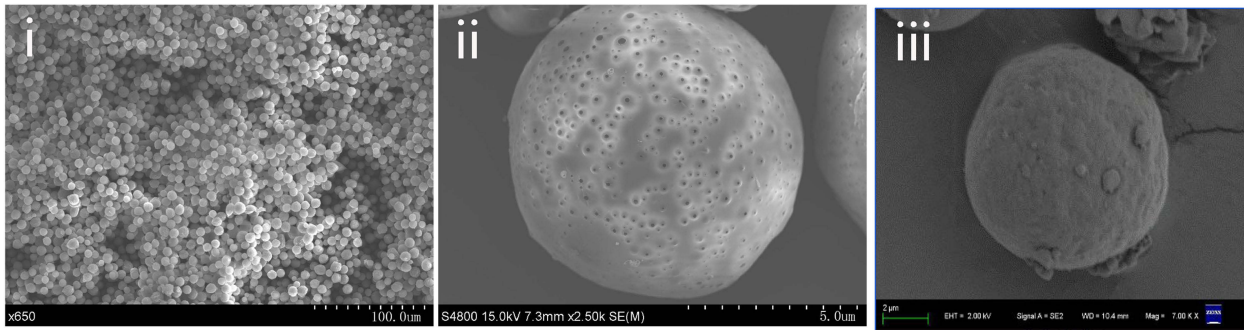

B

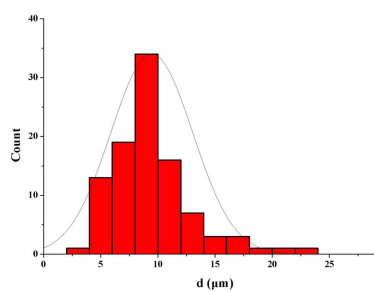

C
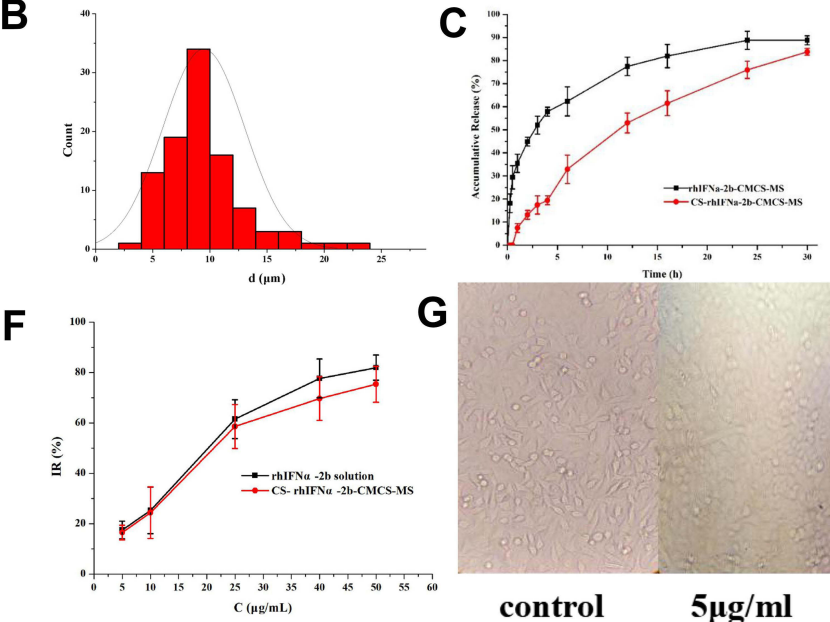

$\mathbf{G}$

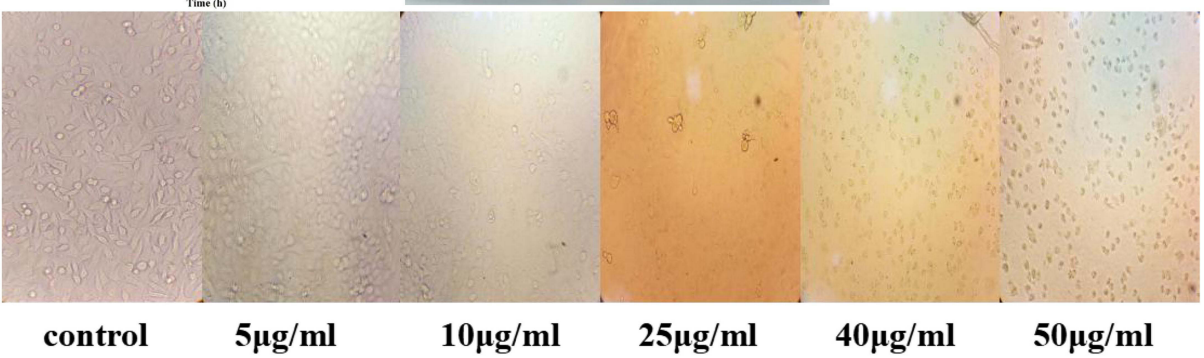

Figure 5 Characterization studies. (A) SEM images (i: CCPM; ii: surface of CCPM; iii: rhIFN $\alpha-2 b-C C P M$; iv: CS-rhIFN $\alpha$-2b-CCPM); (B) Particle size distribution of CSrhIFN $\alpha$-2b-CCPM; (C) Accumulative release from the optimal formulation; (D) Electrophoretogram of different rhIFN $\alpha$-2b samples dyed by Coomassie brilliant blue (a: rhIFN $\alpha-2 b$ solution; b: rhlFN $\alpha-2 b$ extracted from nanoporous microspheres; $c$ : rhIFN $\alpha-2 b$ release solution for 12 hrs; $d$ : rhlFN $\alpha-2 b$ extracted from nanoporous microspheres after in vitro release for $24 \mathrm{hrs;}$ e: rhIFN $\alpha-2 b$ in effluent and washing liquid); (E) Circular dichroism spectra of rhIFN $\alpha$-2b; (F) Inhibition rate of cell proliferation $(n=3)$; and $(\mathbf{G})$ Micrograph of the inhibition effect of the nanoporous microsphere releasing solution with different concentrations on A549 cells. Abbreviations: CCPM, nanoporous microspheres; rhIFN $\alpha$-2b-CCPM, rhIFN $\alpha$-2b carboxymethyl chitosan nanoporous microspheres; CS-rhIFN $\alpha$-2b-CCPM, chitosan rhIFN $\alpha-2 b$ carboxymethyl chitosan nanoporous microspheres; IR, inhibition rate. 


\section{Publish your work in this journal}

The International Journal of Nanomedicine is an international, peerreviewed journal focusing on the application of nanotechnology in diagnostics, therapeutics, and drug delivery systems throughout the biomedical field. This journal is indexed on PubMed Central, MedLine, CAS, SciSearch ${ }^{\mathbb{R}}$, Current Contents ${ }^{\mathbb{R}} /$ Clinical Medicine,
Journal Citation Reports/Science Edition, EMBase, Scopus and the Elsevier Bibliographic databases. The manuscript management system is completely online and includes a very quick and fair peer-review system, which is all easy to use. Visit http:/www.dovepress.com/ testimonials.php to read real quotes from published authors.

Submit your manuscript here: https://www.dovepress.com/international-journal-of-nanomedicine-journal 